\title{
EDITORIAL
}

\section{IN THE AUGUST 2006 ISSUE OF CLINICS}

\author{
Mauricio Rocha-e-Silva, Editor
}

In this August 2006 Issue of Clinics we highlight the novel contribution of Araújo et al, who evaluated the effects of the conjugated equine estrogens and of tamoxifen on the function and morphology of the thyroid gland of ovariectomized rats. Compared to untreated ovariectomized controls, estrogens and tamoxifen induced greater thyroid follicular cell height comparable to that observed in normal rats. T3 and T4 levels were low in the untreated ovariectomized rats, compared to normal rats and to the 2 treated groups. These data indicate that estrogen and tamoxifen administration induce proliferation of the thyroid, an observation which has not been previously described.

Modolin et al present results of the treatment of 17 patients for lymphedema of the penis and scrotum by removing affected tissues and correcting the penoscrotal region, through a modification of the surgical method of Charles. Regression of symptoms and clinical improvement was verified in the follow up which ranged from 6 months to 6 years. The procedure is easily reproducible and allows for improvements in local hygiene and in ambulation, voiding in a standing position, and permits the resumption of sexual intercourse. The cosmetic results are good, and the quality of life is remarkably improvement.

Lucareli et al describe alterations of the load-response mechanism of the knee joint during hemiparetic gait following stroke in 66 patients studied by 3-dimensional kin-

Hospital das Clínicas, São Paulo University Medical School - São Paulo/ SP, Brazil.

Email: mrsilva36@hcnet.usp.br ematic analysis. The clinically relevant characteristics found were an increase in knee joint flexion during the initial contact, and movement amplitude below that anticipated in this phase of the walking cycle. These were the most important alteration of the load-response mechanism in all the studied patients and should be taken into account when choosing the best treatment strategy.

Almeida et al compare the effects of the COX-2 inhibitor parecoxib and a normal saline placebo on a rat model of taurocholate induced acute pancreatitis. IL-6 and IL-10 were lower in the parecoxib-treated group, but amylase levels and mortality were similar. Histological morphology also was unaltered, except for fat necrosis, which was worse in parecoxib-treated rats. They conclude that parecoxib has a poor effect on this model of taurocholate induced pancreatic injury.

Camargo et al determined the prevalence of chronic autoimmune thyroiditis in 409 residents in an urban area neighboring a petrochemical complex, by comparing them to 420 patients in an adequately paired urban control area. A high prevalence of chronic autoimmune thyroiditis was detected in both areas, which may be attributed to a high iodine intake over the 7 preceding years. There was no apparent relationship of chronic autoimmune thyroiditis prevalence to the proximity to the petrochemical complex.

Narazaki et al retrospectively describe the prognostic factors in 112 patients treated for pathologic fractures secondary to metastatic tumors. This case series exhibited a pattern similar to recently described international ones 
(most frequent primary tumor: breast tumor, followed by tumors of undetermined origin, prostate, and lung tumors). The only clear prognostic factor referred to the orthopedic procedure: patients undergoing osteosynthesis, a less morbid surgical technique with earlier rehabilitation, had longer survival times than patients who received endoprostheses.

Valente et al report an interesting and simple tool for diagnostic differentiation between the two relatively uncommon Chédiak-Higashi and Griscelli-Prunieras syndromes. Light microscopic examination of hair shafts of patients reveals subtle differences that are useful in identifying both the disorders, but not in distinguishing between them. However, polarized light microscopy of hair shafts, an approach that has not been previously described, aids in differentiating between these syndromes. The hitherto undescribed differences observed under these conditions are offered as a helpful complementary diagnostic method for differential diagnosis, especially in situations where the more sophisticated molecular studies are not available.

Fernandes et al report a prospective, randomized multicenter study with closed, multi-fragmented tibial diaphyseal fractures treated using one of two fixation methods both performed during minimally invasive surgery: nonreamed interlocking intramedullary nails (23 patients) or bridging plates (22 patients). The healing time was shorter with the bridging plate technique, although no significant functional differences were found.

Nishinari et al report the results of arterial reconstructions associated with the resection of malignant tumors in 36 patients undergoing elective operations between 1997 and 2004. They were classified according to tumor location: cervical (14), lower limbs (13), and abdomen (9). Arterial reconstruction was accomplished in all patients, 5 arterial complications were recorded: 2 early- and 3 latestage. There was no difference between the primary arterial patency rates between the 3 groups of tumor location. All the deaths (22) recorded over this period resulted from progression of the respective neoplasic disease.

We also publish a review on volume management in critically ill patients and 5 case reports.

\section{NO FASCÍCULO DE JUNHO 2006 DE CLINICS}

Neste número de agosto de 2006 de Clinics, destaca-se a contribuição original de Araújo et al, que avaliaram os efeitos de estrógenos eqüinos conjugados e de tamoxifen sobre a função e morfologia da tireóide em ratas ovariectomizadas. Comparadas com controles ovariectomizadas, observou-se que o estrógeno e o tamoxifen induzem maior altura de células foliculares, comparáveis aos níveis observa- dos em ratas normais. Os níveis medidos de T3 e T4 em ratas ovariectomizadas não tratadas foram baixos, em comparação com ratas normais e com as ratas dos grupos tratados com estrógeno e tamoxifen. Estes dados indicam que os estrógenos e o tamoxifen induzem proliferação celular na tireóide, uma observação nunca antes relatada.

Modolin et al apresentam os resultados do tratamento 